\title{
GASTRO-INTESTINAL INFECTION IN RELATION TO INFEC- TION OF THE LIVER AND BILE PASSAGES
}

(A Continuation).

\author{
Br Cilandes G. Stockton, M.D., \\ nuFrato, $\mathbf{~} . \mathbf{Y}$.
}

Résumé of Former Report. In 1916 the patient first appcared, suffering from clebility, hypochlorhydria and lowered nutrition; there were no symptoms related to the liver or to the intestine. She was discharged eight weeks later, showing general improvement, and was in good health until the spring of 1919 , when there developed intractable diarrhea. She returned to Buffalo in September, 1919 , with gastro-enteroeolitis of the greatest intensity in the small intestine and with gas bacilli and streptoeocei abundant. The stomach showed atonic dilatation, achylia, pus cells, red blood cells and an excess of mucus. In November, 1919, the diarrliea was controlled, gastric secretion renppenred and the patient was discharged, taking a smooth diet. Improvement continued for a month, with a gain in weight of fourteen pounds, but she ate too freely and became for the first time jaundiced. On December 24, three weeks later, she came again to Buffalo. There was completc associated jaundice, with acholic stools. A study of the stomach and duodenal contents indicated severe tuodenitis. There was a recurrenee of diarrhea. The liver was cnlarged and slightly tender to pressure, but therc was no pain.

Conclusion. Biliary obstruction from swelling at the ampulln of Vater.

There was slight elevation of temperature and a lcukocyte count of 6100 . Duodenal lavage was practiserl with benefit. The jaundice diminished, became intermittent with oceasionnl rignrs, followed by fever and renewed jaundice with leukocytosis. The clinieal pieture corresponded with the old eonceptions of angioeholitis. The intestine, ineluding the colon, showed atony and catarrhal inflammation. Under deep duodenal feeding, duodemal lavage and colonic irrigations the patient improved. In May, 1920 , recovery seemed possible, as stated at our last meeting.*

Fistory of the Case as Devoloped Subsequent to the Report Made at the Last Meeting of the Association. The patient had almost invariably a good appetite. At times there was slight gastric secretion (hypoehlorhydria), at other times secretion was absent, with evidenee of a low-grade gastritis. Intermittently the stools showed bile coloring matter and bile salts, but not always associated. She was not studied as to the presence of hemoconias.

* Transactinns, twonty-third Annual Session of the American Gastrn-Enterological Association, May 3 and 1, 1020. Seo "Annals nf Medicine," vnl. 1, No. 2. 
In the duodeual contents pancreatic ferments were very deficient. There was feehle amyolitic enzyme, still feebler proteolitic enzyme and usually ahsence of lipase action. Always there was mueus in excess, occurring often in shreds, containing numerous pus cells, at times many degenerated red blood cells.

It was evident that there was an open passage through the bile ducts, but nevertheless infection coming through the biliary channels. This was proved by the use of the duodenal tube after irrigation of the stomach and duodenum. It was also evident that there was a very defective digestive power in the duodenum as result of the disordered panereas and the duodenitis. At tbis time the suggestion was made hy Dr. Rose Donk, who was assisting on the case, that the transfusion of normal duodenal contents from a healthy donor might provide the patient with needed digestive ferments and help her to gain in nutrition. Tbis treatment was carried out by Dr. Donk under my ohservation during a period of two weeks. The healthy donor while fasting, baving bad passed the duodenal tube and having had the secretions stimulated by small quantities of hot water, gave out from 60 to $200 \mathrm{cc}$ of duodenal contents, wbich were immediately introduced through a tube into the duodenum of the patient. The result of this treatment was published by Dr. Donk, under the title "Transfusion of Duodenal Contents." The work was interesting, and unquestionably the patient received temporary bencfit from the mcasure. I am convinced that this suggestion made by Dr. Donk will prove to be of somc practical importance in selected cases.

Intestinal perfusion was also practised at other times, with apparent benefit. A freer flow of bile was promoted by irrigation with magnesium sulphate solution as suggested by Meltzer. The diarrhca never recurred with its former intensity, yet there was a eontinued predisposition to looseness requiring attention and at times special medieation. The sigmoidoseope revealed a catarrhal colitis but no bleeding-points. The patient in Fehruary liad a definite intestinal hemorrhage unexplained in origin.

Medical and surgical consultants leaned to the opinion that there was more trouble in the gall-bladder than had been hitherto helieved. It was suggested that we were dealing with a chronie cholecystitis with calculi. There was no evidence of this, however, in the radiograms which were shown and discussed at our last meeting. To my mind it seemed clear that the trouble was not from the gall-hladder, hut that we had, following the hlocking at the papilla in the beginning of the jaundice, an ascending infection wbich reached tbe liver and probably the pancreas.

During May the case was at a standstill, with an occasional discouraging relapse; that is, chils, fever and leukocytosis, the

2 Jour. Am. Med. Assn., November 13, 1920. 
attaek lasting two or tbree days; then the jaundice would fade, but it never disappeared. It was deeided, finally, that tbere should be made a cholecystostomy, with the hope that by removing a cholecystitis the infection passing into the intestine would be eliminated and that tbe patient migbt be benefited. Also, it would settle the question as to calculi.

The operation was made under gas and etber anesthesia, which was preceded by a transfusion of $750 \mathrm{ec}$ of blood from a well-typed donor. The transfusion was intended not only to strenthen the patient but to inerease the coagulability of the blood, which had been found to be fourteen minutes plus. Following the transfusion, Dr. James A. MacLeod operated upon the patient, remoring the appendix, whicl showed chronic inflammation, and performing cholccystostomy. It was decided to do little exploring, so that the shock might be at the minimum. However, it was found that there was no cvidence of tumor about the stomach or duodemim; the panereas was unusually firm on palpation; the gall-bladder was lot distended but was rather pale, and contained no calculi, but a small amount of ratlicr dark bile of inercased consistency. Thic liver was apparently moderately enlarged, pale yellow in color, ratlier firm upon palpation, with the surface irregular as secn ill cirrloosis. The eommon duct was not explored.

The paticnt cndured the opcration remarkably well and seened to be in better condition after it than before, doubtless from the transfusion. The amount of bilc drainage was small and we felt that littlc was directly gained by the operation. For sone days, lowever, the patient did well, when there ensued anothcr, aurl this time severe, intestinal hemorrhage, and transfusion secmed necessary to save life; 500 ee of blood were therefore introducel into a vein. The blood was taken from a new donor. There was no agglutination slown on typing, but subsequently it was found that the patient's serum hemolyzed the donor's corpuseles. 'Tlicre followed great prostration, with unconseiousness. In the state of dcpression, amounting almost to shock, which followed the sceond transfusion with blood, therc appeared in the urine a large amount of urobilin. Previously it never laad appeared in the urine, and after that event it never disappeared. It is an interesting question as to what effect this transfusion may have had upon tbe liver to hasten its degeneration in its already crippled and infected state. 'Tbere is, of course, the possibility of coincidence, but the clinical fact remains striking. For a few days it looked as though the patient would succumb from hemolysis and protein-poisoning. However, sbe rallied and matters progressed favorably for a few days, although there continued to be marked urobilinuria. At this time drainage of bile was insignificant, and it occurred to me that benefit migbt follow irrigation of the gall-bladder through the drainage tube, with a magnesinm sulphate solution of 25 per 
cent. 'I'his was practised, with the result that the drainage of clark-eolored bile was mueh inereased. There was eonsiderable diminution of the jaundiee, whieh had deepened sinee the operation. I think that real but transient improvement followed this irrigation of the gall-bladder with a magnesium sulphate solution. This was earried out for a month, the patient making slow improvement. The evidenees of infeetion were less eonspienous-that is to say, there was absenee of ehills, but a slight temperature. Under the treatment the liver slirank in size and it was diffienlt to keep a drainage tube in place for purposes of irrigation. Finally, irrigation heeame impossible, the wound healed and the patient was sent to her homc.

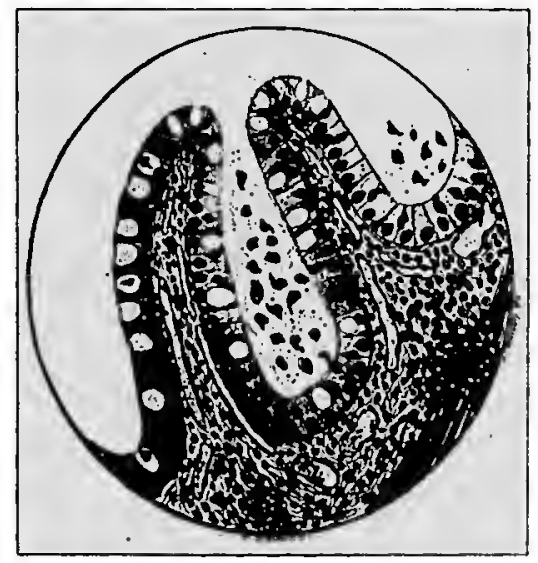

lifu. 1.-Highli-power sketch of intestine witl two villi. Numerous goblet tells among the surfaes cpitledial cells, leukoeytes free loctween the villi nud migrating through the ejithelium; dilnted eapilluries, cell collection in the submucosn, all indicating subacute encritis.

She made the journey of one hundred and fifty miles with little diffenlty, and eontinned with but little change in her condition for about a month, when she somewhat suddenly went into a collapse and died.

Dr. William F'. Jacols, pathologist, aceompanied me to her home and there was made a careful lat incomplete autopsy, limited to the examination of the abdominal viscera. The results of this postmortem sturly were interesting. The stonneh showed dilatstion witl gastritis. From the gross appearanee the mueous tissues of the duodeinun were infiltrated, swollen, intensely red and some- 
what softened. 'This catarrhal state of the intestine wans observed throughont the gnt, being less crilent in the colon than in the simall intestinc, and morc marked in the duodenum than elsewhere. 'There were no adhesions from the appendectom!. 'There were the usual adhesions at the site of the drodenostomy. From mieroscopic sections the tunics of the stomach and intestine showed less inflammatory change than would have been anticipated from their appearance, yet on microseopic section markcl duodenitis was demonstrated. The gall-bladder was contracted but showed no growth on culturc. The biliary passages, including the common duct, eystic duct and hepatic duct, were licalthy. 'There was no cvirlence of calenlus past or present, nor was there evidenee of past cholangitis.

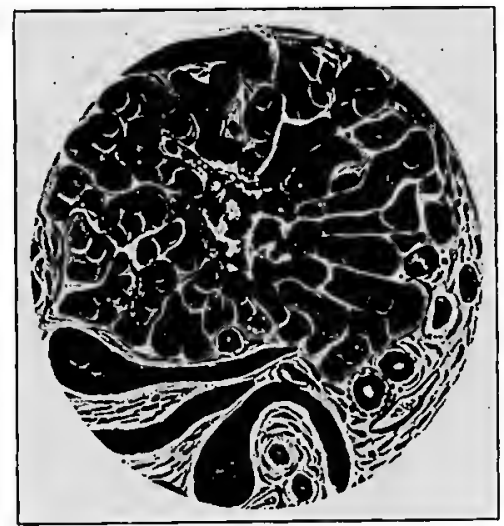

Fro. 2.-High-power diagrammatic sketch of part of a liver lobule, with small central area of necrosis and new-forming bile ducts at the edge.

The striking and interesting features of the case were found in the structures of the liver itself. 'This organ lied shrnuk to perhaps two-thirds its normal volume, which it will be recalled was large during the six montlss preceding thc opcration, and also at that time. It was yellowish, fawn-colored, with small irregnlarities of surface, such as one sces in hepatic cirrhosis. On incision of the liver in all parts of the organ there were found conntless areas of nccrosis, rather dry in character, containing délris. The tissucs presented the picturc of minute areas of hepatitis, in which the biliary passages escapel execpt at their origin, as occurs in hiliary eirrhosis. 'I'here was marked ingrowth of eomertive tissne 
containiug many new-formed bile ducts. The pancreas showed but slight interstitial change; there was no cvidence of actual infection.

From a strictly postmortem point of view it might seem that the process had begun in the liver and that the bile had led to infection of the intestinal tract. Such a conclusion does not correspond with the history of the case. It will bc recalled that the patient suffered primarily from gastritis and failing gastric function, and thrce years later from enteritis, and was subsequently never free from these conditions. There was no jaundice preceding the last eight months of life. It is my own judgment (and I think the morbid

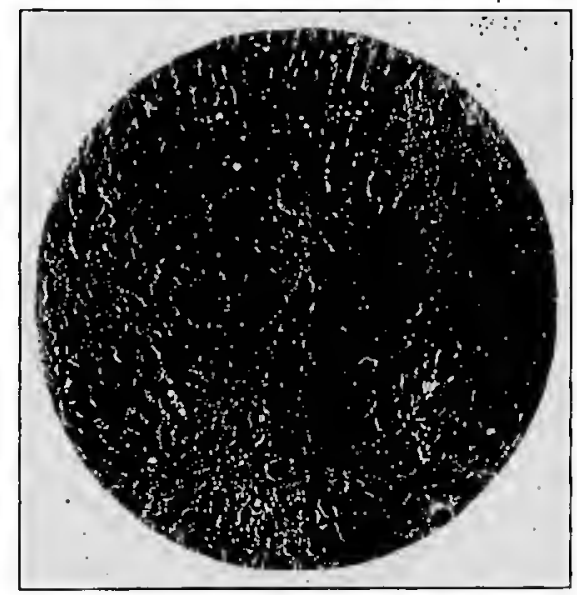

Fra. 3.-Quite low-power photomicrograph of the liver. An aren of well-stnined liver tissue shnding into unstnined nnd necrotic tissue. Also cellulnr fibrous tissue with bile duets.

structures support this view) that the disease was primarily a gastritis, later an intense duodenitis; that there was from swelling of the duodenal mucosa, a blocking at the papilla, which causcd the first attack of jaundice. Meantime infection had been carricd to the liver through the portal system, and thus there was set up a hepatitis with descending inflammation, and not one that ascended through the biliary tract, as I had naturally inferred. I fecl that this statement is worthy of repetition and emphasis, for the reason that this case seems to illustrate the growing belief that jaundice is more often the result of an infective or toxic hepatitis, with the infection descending, than an ascending infection; that is to say, 
the infection reacbes the liver through tbe portal system, and the obstruction to the outflowing bile occurs in and about the lobules and possibly at the beginning biliary passages. This is not to deny the well-known fact that jaundice often arises from obstruction at the common duct or the hepatic duct, and this obstruction may, of course, be inflammatory Except in the instance of calculi causing actual obstruction at the junction of the cystic and common ducts or in the ampulla, jaundice is probably ratber rare from simple angiocholitis of ascending nature.

There arc the following outstanding features to the bistory of the case:

1. The relationsbip tbat may exist between bepatitis with necrotic areas, later replaced by interstitial ingrowth on the one band, and on the other hand persistent gastro-enterocolitis, in some regions intense.

2. With this pathology, nevertheless, there was escape from involvement or inflammation of the chief bile channels and the gall-bladder, as shown during life by operation and later by postmortem.

3. The illustration of possibly beneficial results from a novel metbod of treatment, that of transfusion of the normal duodenal content of a bealtby donor into the functionless duodenum of a patient, also the value of intestinal perfusion.

4. The remarkable cffect in stimulating the flow of bile from a badly discased liver by direct irrigation of the gall-bladder with a magnesium sulphate solution. This also is, so far as I know, a novel measure of treatment, and is interesting to compare with the method of stimulating thc outflow of bile as described by Vincent Lyoll.

\title{
CALCIFICATION OF THE PITOITART WITH HYPOPITUITARISM AND WITH SEMPTOMATIC TREATMENT.*
}

\author{
By George E. Pfakler, M.D., \\ AND \\ Robert L. Pitfield, M.D., \\ FIILADELPHA, PA.
}

IT has been said by someone that the pituitary is the "gland of personality." To this migbt be added "It is the gland of romance." Not only bas it a great deal to do with physical and mental vigor, the stature, form, color and amount of hair, sex characteristics and pbysical strength, all being controlled by this bean-sized organ

* Read before the Section on General Medicine, College of Physioiant, Philadelphis, May $30,1921$. 